\title{
HUMAN RIGHTS: PEACE, EQUALITY, DIGNITY, JUSTICE, FREEDOM
}

\author{
Prof. Rupali Dnyaneshwar Raghatate \\ Department of Management Studies \\ Bapurao Deshmukh College Of Engineering Sevagram Wardha
}

\begin{abstract}
Until justice rolls down like water and righteousness like a mightystream"

- Martin Luther King

Article one of the Universal Declaration of Human Rights, 1948 states that "All people at large are born loose and same in dignity and rights." this text describes that elementary rights are inalienable offer of humans and might not be taken aloof from them at a lower place any circumstances, whatsoever. Doubtlessly, Human Rights are a criterion of the educated, advanced, developed and civilized nation. These rights have a tendency to contain of the proper to live; the right to exist; the proper to quality; the right to freedom of speech; the proper to expression; the proper to residence, movement, association; the proper to apply any profession; the right con to exploitation; prohibiting all types of variety of pressured labour, baby labour and trafficking, slavery etc, and; civil rights in topics of employment. These rights are the utmost precious and valuable assets that are to be preserved at any value in the other case existence would become unendurable. The diminution of those rights would honestly in some unspecified time in the future cause humiliation and mortification of human existence. Through the have a glance at and coaching of human rights as the way of lifestyles, might want to lend a helping hand to get rid of poorness, ignorance, prejudices, and discrimination supported sex, caste, religion, and incapacity etc amongst the individuals.
\end{abstract}

Keywords - Human Rights, Fundamental Rights, Exploitation, Most Valuable, Mortification, Human Existence

\section{INTRODUCTION}

The individual, however, had no identity of their own as a result of the state was constantly given Associate in Nursing utmost importance. as a result of the society grew and evolved, "Human Rights" were verified to be of greatest significance. once the formation of world organisation Human Rights were universally originated and recognized. These rights are universal which means they belong to everyone and can't be off from them. Human Rights tend to easily settle for each and every individual's talent and skills and claim that noone is inferior or superior to a special. These rights are delineate below three types - one. the basic freedoms or classic civil liberties, 2. Ethnic and non secular rights and, 3. Socio-economic rights.

The idea of equality before law implies that persons or groups shouldn't be discriminated against whereas not justification. These rights aren't created by any law-makers that's why Human Rights are thought-about to be "Natural Rights."

There are total six options of Human Rights:

1) Universal: These rights belong to everybody no matter their sex, caste, color, creed, race, religion, economic state and place of birth.

2) Inalienable: These rights can't be transferred from one person to a different as nobody offers these rights and a private is entitled to those rights by birth. they're conjointly termed as "birth rights."

3) Inherent in Nature: These rights, being the birth right inherent all told the people no matter their caste, color or creed.

4) Natural Rights: they're not crested by any legislative assembly in order that they assume the position of natural rights.

5) Reticular and Indivisible: These rights are categorised into - civil and political rights, economic, social and cultural rights. each right depends on another and that they can't be practiced while not different rights.

6) Elementary for Human's Existence: they're the eternal a part of the character of masses and are essential for the event of human temperament and individual qualities.

\section{HISTORICAL [PAST EVENTS] OF HUMAN RIGHTS}

In, $539 \mathrm{BC}$, prince the good, following overcoming the town of urban center, accomplished one thing fully sudden-he liberated all captives to come home. additionally, he declared people need to choose their terribly own faith. The prince Cylinder, a mud pill containing his announcements, is that the principal human rights statement ever. 


\section{The Magna Charta [1215]:}

The Magna Charta, or "Incredible Charter," was on the face of it the hugest early impact on the broad recorded procedure that prompted the quality of sacred law these days within the English-talking world.

In 1215, following John Lackland of England abused numerous previous laws and traditions by that England had been administered, his subjects unnatural him to sign the Magna Charta, that counts what later came to be thought of as human rights. Among them was the privilege of the congregation to be free from legislative resistivity, the privileges of each free native to possess and acquire property and to be protected from over the highest duties. It established the privilege of widows who possessed property to come to a decision to not hook up with, and established standards of honest treatment and fairness below the watchful eye of the law. It in addition contained arrangements precluding pay off and official unfortunate behavior.

Broadly saw as a standout amongst the foremost imperative authoritative reports within the advancement of current majority rules system, the Magna Charta was a imperative shaping moment within the battle to line up chance.

\section{UNIVERSAL DECLARATON OF HUMAN RIGHTS}

At the purpose once the organizers of the assembled countries met at San Francisco gathering in 1945 to draft the sanction of the unified countries, Spanish American states specifically required the meeting to look at a world bill of human rights.

After the assembled countries contract came into power, the foremost essential trip before the unified countries was the execution of the standards of the regard for Human Rights and central opportunities for all while not refinement on race, sex, language, or faith, as set down below article fifty five of the U.N. Contract. In, 1946 the financial and social board formally supported the read that the rationale for the unified countries with relevance the advancement and perception of human rights may well be glad simply if the arrangement was created for a worldwide bill of rights and for its execution.

The General Assembly eluded this issue to the Economic and Social Council for concentrate by the commission on Human Rights was driven by 'the desire to make up a way reaching framework for the advancement and security of human rights'. The Commission in Jan 1947 delegated a Committee called Drafting Committee for the readiness of the draft of the Bill of Rights.

Preamble to Universal Declaration of Human Rights:
The seven paragraphs of the preamble kicked off the explanations or the destinations of the affirmation that is trailed by an announcement "broadcasting" the Declaration.

Para I: Asserts that the popularity of human dignity of all individuals is that the foundation of justice and peace within the world.

Para II: Observes that disregard and contempt for human rights have resulted in barbarous acts that have indignant the conscience of group which the four freedoms: freedom of speech, belief, freedom from wish, and freedom from concern are "proclaimed because the highest aspiration" of the individuals.

Para III: States that folks aren't compelled to rebellion against tyranny; human rights ought to be protected by rule of law.

Para IV: Relates human rights to the event of friendly relations between nations.

Para V: Links the declaration back to the UN Charter that reaffirms religion in basic human rights and dignity and price of the human person.

Para VI: Observes that "a common understanding" of rights and freedom is of "the greatest importance" for the complete realization of that pledge.

\section{VULNERABLE GROUPS AND HUMAN RIGHTS}

\section{Rights of women:}

For a substantial length of your time past, women everyplace throughout the globe haven't completely been denied full equity, social, financial, and political but as a "flimsier area" they need been utilised, mishandled, misused and later disposed of to guide indecent, road vagrant and down and out life until their passing. To battle socio-lawful viewpoint with relevancy the rights distinctive with women, presently endeavors are embraced each generally and universally. Ladies' rights are the principal human rights that were revered by the global organization for every person on the world concerning seventy years back. These rights incorporate the privilege to measure free from savagery, subjugation, and segregation; to be instructed; to say property; to solid a ballot; and to win an inexpensive and equivalent compensation. To combat this, the national in addition as international community has since ages tried to play a decisive role in protective human rights of ladies. varied documents that have cause the protection of rights of ladies are as follows:

The Indian legal code itself contains several provisions pertaining specially to girls. They are:

SECTION 228A- penalty for speech act of the identity of victim of sure offences like rape;

SECTION 304B - gift death; 


\section{International Journal of Engineering Applied Sciences and Technology, 2020 \\ Vol. 5, Issue 2, ISSN No. 2455-2143, Pages 650-655 \\ Published Online June 2020 in IJEAST (http://www.ijeast.com)}

SECTION 354- Outraging the modesty of a woman;

SECTION 361- seizure from lawful guardianship;

SECTION 363- penalty for kidnapping;

SECTION 366- seizure, abducent or causing girls to compel her wedding etc.;

SECTION 366A- facts of life of minor girl;

SECTION 366B- Importation of woman from foreign country;

\section{SECTION 375- Rape}

SECTION 494- Marrying once more throughout period of husband or wife;

SECTION 489A- Harassment and Cruelty

\section{2) kid Rights:}

Adolescence will and may be protected. youngsters reserve the choice to endure, create, be ensured associate degreed take an interest in decisions that sway their lives. youngsters are natives in their terribly claim, qualified for the complete vary of human rights. The essential purpose behind insurance of privileges of children may be a direct results of the approach that the youngsters are additional helpless than grown-ups to the conditions beneath that they live. they're honest, trusting and brimful with expectation. In any case, for a few children, the reality of youth is by and enormous extraordinary. Directly through the history, youngsters are manhandled and misused. They expertise the sick effects of craving and uncovered poverty-stricken. they need worked in harmful conditions.

Article twentyfour of the International Covenant on Civil and Political Rights (ICCPR) provides:

"(1) each kid shall have, with none discrimination on race, color, sex, language, religion, national or social origin, property or birth, the correct to such measures of protection are pro re nata by his standing of a minor on the a part of his family, society and therefore the State;

2) each kid shall be registered instantly when birth and shall have a reputation.

3) kid has the correct to amass position.

\section{3) Disabled Persons:}

In far more than five hundred million individuals ten $\%$ of the whole population, associate degree expected eighty $\%$ of them living within the making World, experiences the sick effects of either mental or physical incapacity. Of these, three hundred million are within the making and developing nations and one thing like a hundred million of these are accepted to be in India. A handicap is often characterised because the failing, aggravation or misfortune within the typical operating of physical, mental or mental procedures or a bother within the capability to be told, or alter socially that meddles with associate degree individual's normal development and advancement. whereas a handicap may be an issue old by an individual attributable to the character of the atmosphere during which he finds herself.

The British Council defines incapacity as "the disadvantage or restriction of activity caused by a society that takes very little or no account of individuals who have impairments and therefore excludes them from thought activities"

\section{Declaration on the Rights of Disabled Persons (1975)}

On Dec nine, 1975, the overall Assembly adopted, the Declaration on the Rights of Disabled Persons wherever the term 'disabled person' was outlined as 'any person unable to make sure by him or herself, totally or partially, the wants of a standard individual and or social life.

It primarily proclaims the subsequent rights of the disabled persons:

1) Equal civil and political rights of disabled persons, the inherent right to respect for his or her human dignity.

2) identical basic human rights regardless of the origin, nature and seriousness of theirHandicaps and disabilities as their fellow voters, together with the correct to a good life (both economically and socially) as traditional and full as doable.

3) Right to measure with their families or with foster folks.

4) Right to protection against exploitation or discriminatory, abusive or degrading treatment.

5) Right to qualified legal help to safeguard their rights and for legal procedures to require their condition absolutely under consideration.

\section{4) Autochthonal People:}

Indigenous people or native individuals are the individuals who were living on their properties before pilgrims originated from elsewhere. At the top of the day, those who occupy a land before it absolutely was vanquished by frontier social orders(known as colonials) who read themselves as specific from the social orders right away overseeing those domains are 


\section{International Journal of Engineering Applied Sciences and Technology, 2020 \\ Vol. 5, Issue 2, ISSN No. 2455-2143, Pages 650-655 \\ Published Online June 2020 in IJEAST (http://www.ijeast.com)}

referred to as autochthonal individuals or 1 st individuals or social group people, in addition aboriginals. They structure at the moment nonoverwhelming divisions of society and are resolved to safeguard, create, and transmit to future ages their hereditary regions, and their ethnic temperament, because the premise of their proceeded with presence as people, as per their own social examples, social institutions and bonafide frameworks. autochthonal people carry on conventions that are pursued for ages. they need created through attack and organisation whereas heretofore maintaining their traditions. they need a definite culture, social establishments and religions.

\section{DECLARATION ON THE RIGHTS OF AUTOCHTHONAL PEOPLE:}

There are forty six Articles, or rules, within the Declaration, including:

1) autochthonal peoples are free and capable all others and have the correct to be free from any reasonably discrimination, together with discrimination supported their autochthonal origin or identity (Article 2). autochthonal individuals have the correct to measure in freedom, peace and security.

2) they have to be free from killing and alternative acts of violence together with the removal of their youngsters by force (Article 7).

3) autochthonal peoples have the correct to follow and revitalize their cultural traditions and customs (Article 11).

4) autochthonal peoples shall not be aloof from their land by force. wherever they agree, they ought to be provided compensation, and, wherever doable, have the chance to come (Article 10).

5) autochthonal peoples should not be discriminated against in matters connected with employment (Article 17).

6) Governments shall consult properly with autochthonal peoples before adopting laws and policies that will have an effect on them. they have to use the principles of free, previous and consent which suggests giving autochthonal peoples all the facts required to form choices (Article 19).

7) autochthonal peoples have the correct to possess, use and management their lands, waters and alternative resources. Governments shall acknowledge and shield these lands, waters and resources (Article 26).

\section{5) Prisoner's Rights:}

Prisoner's Rights Law deals with the rights of inmates whereas behind bars. several of those laws relate to basic human rights and civil liberties. Prisoners and detainees are in addition qualified for rights to some extent as a typical individual after they are behind the jail. These rights are given beneath the Constitution of India, the Prisons Act, 1894 and then forth. Prisoners tend to own many rights and that they don't lose their basic constitutional rights. jail walls don't prevent basic rights. The Supreme Court has stressed that a unfortunate person, whether or not a convict, undertrial or pawl, doesn't stop to be a personality's being and, whereas lodged in jail, he enjoys all his basic rights secure by the Constitution of India together with the correct to life guaranteed by the Constitution.

The provisions of the document that we tend to are involved with rights currently are as follows:

1) Article fourteen of the Constitution of India says that the State shall not deny to somebody equality before law or the equal protection of laws inside the territory of India.

2) Article nineteen of the Constitution of India guarantees six freedoms to the all voters of India. Among these freedoms sure freedoms cannot enjoyed by the prisoners attributable to the terribly nature of those freedoms.

3) Article twenty one of the Constitution of India says that not a soul shall be bereft of his life or personal liberty except per procedure established by law.

\section{COLLECTIVE RIGHTS}

Universal agreement on common and political rights and world contract on financial, social and social rights began varied rights to individuals which could be delighted in by them one by one by ethicalness of their being human. each the agreements whereas giving rights to people have utilised the words in varied Articles, as an example, 'each one', 'each individual' and 'all people's who infer that rights documented within the pledges vest in them. These rights for comfort can be alluded to customary rights. nonetheless those rights, there's another type of rights that is alluded to as mixture rights.

\section{EXAMPLES OF COLLECTIVE RIGHTS:}

1) the proper to talk one's language and educate kids therein language; the right to cultural preservation.

2) The rights of native peoples to land and resources control put together, and also the right to pass land and resources down through the generations.

3) the proper to development.

\section{HUMAN RIGHTS AND NON-GOVERNMENTAL ORGANISATIONS}




\section{International Journal of Engineering Applied Sciences and Technology, 2020 \\ Vol. 5, Issue 2, ISSN No. 2455-2143, Pages 650-655 \\ Published Online June 2020 in IJEAST (http://www.ijeast.com)}

The humanitarian conception of protection and care of the individuals and notably the deprived is a very important issue of international concern and had been well-established within the thinking of the eminent jurists. within the initial stages, for achieving this goal the International Human Rights Organizations were based by League of states and UN. London primarily based Anti- Slavery Society for Human Rights in 1938, the International Committee for nongovernmental organization in 1963, the French League for Human Rights in 1898. an oversized variety of NonGovernmental Organization (NGO) at national, regional and native level emerged once 1970.

Article seventy one of the international organisation Charter provides that the Economic and Social Council (ECOSOC) might build informatory arrangements with NGOs. the quantity of NGOs having informatory standing has grownup steady since the creation of the international organisation Charter.

1) Agenda: Right to receive the tentative agenda of Economic and Social Council or its subsidiary bodies and to propose the inclusi9on of latest agenda things.

2) Attendance: NGOs are entitled to attend public conferences of Economic and Social Council and its subsidiary bodies. Written Statements: NGOs might submit statements and have them circulated to Economic and Social Council and its subsidiary bodies.

3) Oral Interventions: counting on their class, NGOs have the proper to form oral statements before Economic and Social Council.

\section{IMPLEMENTATION OF HUMAN RIGHTS}

Human Rights Commission in India:

Since the formation of the UN the globe has been sensitive and responsive towards its duty concerning the handling of the human rights. Bharat was additionally aware to react to the foremost needed side of human life. this is often significantly apparent because the rights incorporated within the Universal Declaration of Human rights were created a region of the Constitution of Bharat either in the sort of basic Rights or the Directive Principles of State Policy.

In pursuance with the protection of the Human Rights Act of 1993 the primary National Human Rights Commission of Bharat was accepted on twenty nine Sept 1993, with Shri Ranganath Mishra, the ex-chief justice of Bharat as its 1st presiding officer.

\section{Human Rights Commission (NHRC):}

National Human Rights Commission (NHRC) of Bharat may be a self-ruling open body responsible of the insurance and advancement of human rights, characterised by the Act as "rights distinguishing with life, freedom, uniformity and poise of the individual ensured by the Constitution or epitomized within the International Covenants".
Chapter II of the Act deals with the Constitution of the National Human Rights Commission. Section three provides for the putting in place of a body by the Central Government referred to as the National Human Rights Commission. the subsequent shall be the constitution:

Chairperson: former magistrate of the Supreme Court.

Other Members: a sitting or needed choose of the Supreme Court, a serving or a retired magistrate of the court, 2 distinguished persons having information or sensible expertise within the sphere of human rights.

The Chairpersons of the National Commission for Minorities, the scheduled Castes and scheduled Tribes and girls shall be members sure such functions.

The Commission shall have a secretary-general who can discharge his functions keeping with the powers delegated to him.

\section{CONCLUSION}

Human rights are those nominal rights which each and every individual should have by virtue of his being a 'member of the human family' no matter the other thought. the UN has succeeded in making awareness among all for worldwide.one of the key achievements of the UN was the adoption of the Universal Declaration of HUMAN RIGHTS, 1948 they're supported mankind's demand for a life during which the inherent dignity of the individual can receive respect and protection. they're forming the foundations of a society and that they are inviolable, because the society would disintegrate, if they're desecrated. The new Human Rights Council, created by General Assembly by its Resolution 60/251 on fifteen March 2006 there's a growing rhetoric within the recent past on the promotion and protection of human rights round the world. this is often thanks to the rank and blatant violations of human rights would like a contributing and sanctioning surroundings, above all to acceptable rules, establishments and procedures framing the sections of the govt. in a very method that promotes and protects human rights.

A) Protection of Human Rights Act ought to be amended to make sure associate degree enforceable right to compensation for unlawful detention or arrest;

B) In curb the menace of protective violence, Bharat ought to straight off sign the United Nation Convention against Torture.

C) rising capacities and confidence a lot of thus within the case of weak and underprivileged to face and kindle social control, protection and preservation of their rights;

D) making completely different reasonably information, innovating or reforming structure making and transmission new skills, coaching and competencies execution these 


\section{International Journal of Engineering Applied Sciences and Technology, 2020 \\ Vol. 5, Issue 2, ISSN No. 2455-2143, Pages 650-655 \\ Published Online June 2020 in IJEAST (http://www.ijeast.com)}

policies human rights in discharging their functions beneath the jurisdiction.

\section{REFERENCE}

[1] Badan Pusat Statistik Kota Balikpapan. (2019, May 16).

Proyeksi Penduduk Kota Balikpapan Menurut Kecamatan Tahun 2010-2018. Retrieved from Statistics Balikpapan: https://balikpapankota.bps.go.id/statictable/2018/01/19/54 /proyeksi-penduduk-kota-balikpapanmenurut $\square$ kecamatan-tahun-2010-2017.html

[2] Balikpapan, P. K. (2016). Laporan Kinerja Instansi Pemerintah Kota Balikpapan. Balikpapan: Balikpapan Government.

[3] Bornstein, M. H., Britto, P. R., Nonoyama-Tarumi, Y.,

Ota, Y., Petrovic, O., \& Putnick, D. L. (2012). Child Development in Developing Countries: Introduction and Methods. Child Development Journal, 83(1), 16-31. doi:https://doi.org/10.1111/j.1467-8624.2011.01671.x

[4] Britto, P. R., \& Ulkuer, N. (2012). Child Development in Developing Countries: Child Rights and Policy Implications. Child Development Journal, 83(1), 92-103. doi:https://doi.org/10.1111/j.1467-8624.2011.01672.x

[5] Chotib. (2008). Urbanisasi dan Migrasi di Kota Depok, Jawa Barat. Warta Demografi, 38(1), 7-16.

[6] Fajriah, L. R. (2016, January 4). Angka Kemiskinan Meningkat Tembus 28,51 Juta Orang. Jakarta.

[7] Herawati, T., \& Endah, N. Y. (2016). The Effect of Family Function and Conflict on Family Subjective Well-being with Migrant Husband. Journal of Family Sciences, 1-12. doi:https://doi.org/10.29244/jfs.1.2.1-12

[8] Mustofa, M. (2010). Kriminologi: Kajian Sosiologi Terhadap Kriminalitas, Perilaku Menyimpang dan Pelanggaran Hukum (2nd ed.). Bekasi: Sari Ilmu Pratama (SIP).

[9] Mutmainnah, A., Kolopaking, L. M., \& Wahyuni, E. S. (2014, Juli). Urbanisasi di Kota Balikpapan: Formasi Sosial Keluarga Pendatang Miskin. Jurnal Ilmu Sosial dan Ilmu Politik, 18(1), 51-65. Retrieved from

https://journal.ugm.ac.id/jsp/article/view/13098/9328

[10] Noora. (2018, Februari). Social Agency Services for Children with Social Welfare Problem. (H. F. Butar,
Interviewer)

[11] Ombudsman. (2018, February 23). Kabar Perwakilan. Retrieved from Ombudsman Republik Indonesia: https://ombudsman.go.id/perwakilan/news/r/pwk-kekerasan-seksual-mendominasi

[12] Susanti, E. (2013, Juni). Upaya Pencegahan Terhadap Pekerja Anak di Kota Balikpapan. Jurnal Risalah Hukum, 9(1), 25-38.. Hsu and J. Wu, "Multi-resolution Watermarking for Digital Images", IEEE Transactions on Circuits and Systems- II, Vol. 45, No. 8, pp. 1097-1101, August 1998.

[13] R. Mehul, "Discrete Wavelet Transform Based Multiple Watermarking Scheme", in Proceedings of the 2003 IEEE TENCON, pp. 935-938, 2003.

\section{AKNOWLEDGEMENT}

Firstly I would like to express my deep gratitude to Principal Dr. G. V. Thakre for their patience guidance enthusiastic encouragement and useful critiques of their research I would like to express my very great appreciation to HOD. Dr. Ram O. Panchariya \& Dr. Suhas B. Diwate my research supervisors for his valuable \& constructive suggestion during the planning $\&$ development of this Research work. I would also like to thanks Prof. Swapnil S. Kitey for his advice \& assistance in keeping my progress on schedule. I would also like to extend my thanks to the Prof. Pankaj D. Raghatate for his techniqual valuable support his willingness to give his time so generously has been very much appreciated. I Would like to thanks various people for their contribution to this paper.

Finally I wish to greatful thanks my parents for their moral support and encouragement throughout my research study. 